\title{
ПЕРШОДЖЕРЕ ДА
}

\section{Микола Симчич \\ ІНОКЕНТІЙ ГІЗЕЛЬ: ДЕЯКІ МЕТАФІЗИЧНІ ПИТАННЯ 3 КУРСУ ФІЛОСОФІї}

Філософський курс Інокентія Гізеля, що має назву «Твір про всю філософію» (Opus totius philosophiae), було прочитано в Києво-Могилянській академії (далі КМА) у 1645/46-1646/47 навч. pp. Історична цінність курсу підсилюється тим, що він $є$ першим повним філософським курсом, прочитаним у КМА. Курс цікавий суттєвою відмінністю від шаблону, що панував у Академії. На відміну від більшості професорів КМА, Гізель не приймав проглядів єзуїтської школи (Суарес, Уртадо де Мендоса, Аріяга), натомість симпатизував томістам і скотистам.

Томісти і скотисти - дві найвідоміші школи схоластичної філософії, між якими протягом століть точилась гостра полеміка. Як не дивно, Інокентій Гізель намагається знайти примирення для цих шкіл. Його філософський курс є своєрідною «еклектикою». В одних випадках автор приймає погляди томістів, в інших - скотистів, а місцями вважає, що позиції обох шкіл є однаково правильними, а розрізняються суто номінально [Симчич, 2010; Стратій, 2010, Пітч, 2010].

Філософський курс Інокентія Гізеля уже частково знайомий сучасному читачеві. У 2011 році був виданий критичний текст і український переклад фрагментів цього курсу. Тоді вийшли друком два трактати з логіки («Про розрізнення» і «Про універсалії»), а також «Трактат про душу» [Гізель, 2011].

У цій публікації читачеві пропонується уривок Гізелевої метафізики. Подається розшифрований текст рукопису і український переклад. Взято три розділи (sectio) одного питання - «Питання про різні поділи сущого» (Quaestio de variis divisionibus entis):

1) «Розділ про сутність й існування» (Sectio de essentia et existentia),

2) «Розділ про індивідуацію» (Sectio de individuatione),

3) «Розділ про субсистенцію» (Sectio de subsistentia).

Текст цих розділів розміщений на арк. 628 зв. - 634 зв. рукопису Мел.м./п128 Інституту рукопису НБУВ - єдиного збереженого рукопису філософського курсу Інокентія Гізеля.

Перш ніж подати текст Гізеля, зроблю короткий екскурс, присвячений особливостям тих проблем, які розглядає автор.

(C) М. Симчич, 2013 


\section{Проблема розрізнення сутності та існування}

У схоластичній філософії проблема розрізнення сутності (essentia) та існування (existentia або esse) викликала багато суперечок. Майже всі схоласти погоджуються, що поняття «сутність» та «існування» відіграють фундаментальну роль в онтології. Сутність визначає те, чим є річ, тобто, які характерні ознаки вона має. Натомість існування (чи буття) визначає, що ця річ існує. Наприклад, візьмімо таку річ як стіл, що є зараз переді мною. Завдяки сутності стіл відрізняється від стільця, шафи й решти предметів, а завдяки буттю він існує цієї ось миті.

Тома Аквінський, а відтак й інші томісти, вважає, що сутність та існування розрізняються реально. Реальне розрізнення між цими поняттями $є$ істотним пунктом усієї онтологічної побудови Ангельського Доктора. Він вважає, що справжнім буттям є лише Бог, відповідно сутністю Бога є буття, таким чином буття Бога і Його сутність тотожні. Натомість створіння одержують своє буття від Бога, тому в них буття й сутність мають розрізнятися незалежно від нашого пізнання, отже, реально. Саме завдяки такому підходу до розуміння буття св. Тома не міг погодитися 3 онтологічним доказом існування Бога. Він вважає, що сутність може бути поза буттям. Якщо взяти, наприклад, Пегаса, ми всі розуміємо, що він має сутність бути конем 3 крилами. Але він не має ніякого буття поза нашою думкою про нього. Так $\mathrm{i}$ поняття Бога як абсолютної істоти визначає сутність Бога, а не Його буття.

Багато інших філософів, зокрема Генрих Гентський і Йоанн Дунс Скот, не могли погодитися 3 реальним розрізненням між сутністю й існуванням. Вони не можуть погодитися не стільки з тим, що ці онтологічні поняття є відмінними, скільки $з$ тим, що тут має застосовуватися саме реальне розрізнення. Дунс Скот, зокрема, вважає, що реальне розрізнення - це те розрізнення, що існує між двома окремими речами. Відповідно, якщо ані сутність, ані існування не $є$ окремими речами, то вони не можуть розрізнюватися реально.

Для розрізнення сутності та існування Дунс Скот використовує особливий вид розрізнення - формальне розрізнення з природи речі (distinction formalis ex natura rei). Це розрізнення $є$ винаходом Дунса Скота i широко пропагувалося Скотовими послідовниками. Його використовували не лише щодо сутності й існування, але й для розрізнення метафізичних ступенів. Суть підходу полягає в тому, що з природи речі, тобто в дійсності, розрізнювані сутності володіють певними харатеристиками формальностями (formalitates). I оскільки кожна 3 розрізнюваних речей має свої формальності, вони є різними. Формальне розрізнення з боку речі є чимось більшим, ніж розумове, але, безперечно, менше ніж реальне розрізнення. (Cf. [Owens, 1968; Macdonald, 1984]).

\section{Проблема індивідуації}

Здебільшого схоластичні філософи визнавали, що кожна окрема річ, - індивідуум - неподільна в собі й відмінна від інших сущих. Якщо вдатись до попереднього прикладу, це означатиме: коли стіл розділено на частини, він перестає бути собою. При цьому наш стіл є чітко відмінний від інших столів, як і всіх інших речей. Ці дві поєднувані властивості сущого зазвичай називають принципом індивідуації. Принцип індивідуації є досить комплексним концептом і містить різні аспекти. По-перше, це відмінність індивідуума від родів і видів. Це, наприклад, співвідношення стола, що є зараз переді мною, з поняттям стола, а також з поняттями меблів, предметів 
побуту тощо. По-друге, це фізична властивість речей, які при поділі втрачають свою сутність. По-третє, це логічна властивість індивідуума, який не може займати місце предиката у судженні. Схоластів, проте, цікавили не тільки ці питання - їм було важливо знати, завдяки чому конкретна річ $є$ індивідуальною. Філософи, що підтримували реалістичне розв'язання проблеми універсалій, намагалися знайти щось, що із загальних видів утворює індивідуальну річ.

Під впливом Платона і Арістотеля багато середньовічних філософів вважали, що матерія $є$ принципом індивідуації. Згідно з таким поглядом, кожна річ має форму і матерію. Форма визначає сутність речі і $\epsilon$ загальною, тобто належить багатьом індивідуальним речам одного виду. Натомість матерія $є$ особливою в кожному індивідуумі й визначає його індивідуацію. Таку позицію обстоювали також арабські філософи Аль-Фарабі, Авіценна, Авероес. Серед філософів середньовічного заходу цю теорію підтримували Альберт Великий, Сігер Брабантський, Егідій Римський i, насамперед, Тома Аквінський.

Аквінат обстоював думку, що матерія як така - чиста матерія - спільна для всіх індивідуумів, тому не $\epsilon$ принципом індивідуації. Натомість цим принципом $\epsilon$ означена матерія (materia signata), тобто матерія, пов'язана з кількістю. Цю теорію на всіх етапах своєї творчості визнавав св. Тома, а згодом іiі пропагували його послідовники і коментатори: Каєтан, Йоан від св. Томи (Жуан Пуансо) і Сильвестр Ферарський.

Вчення про матерію як принцип індивідуації позначилося й на інших аспектах філософського вчення Аквіната, наприклад, на ангелології. Оскільки ангели не мають матерії, то не існує й принципу їхньої індивідуації. Таким чином, кожен ангел - це окремий вид, адже види розрізняються за формою.

Проте у середньовіччі були філософи, які вважали, що принцип індивідуації навіть матеріальних індивідуумів - це форма. Так, Гільберт Поретанський вважав, що кожен індивідуум - це унікальний набір форм. Форма як така не спричинює індивідуації, а от набір різних видових і родових форм робить конкретну річ індивідуальною.

Натомість св. Бонавентура вважав, що принципом індивідуації є поєднання матеpiї і форми. На його думку, навіть ангели мають матерію, тільки особливу, духовну.

Дуже цікаве розв'язання проблеми індивідуації запропонував Йоан Дунс Скот. Він вважає, що кожна окрема річ, окрім загальної форми, мусить мати додаткове позитивну сущність (entitas), яке визначає іiі індивідуацію. Цим сущим є оцейність (haecceitas). Оцейність - не додаткова форма, а індивідуальна відмінність (differentia).

Філософи номіналістичного спрямування не бачили жодної потреби шукати принцип індивідуації. На думку Вільяма Оккама, Дюранда Сан-Пуарсенського, Петра Ауреолі й Франсиска Суареса, кожне суще, оскільки воно існує, є індивідуальним. Індивідуація - це фундаментальна онтологічна даність. Кожне суще є принципом власної індивідуації. (Cf. [Gracia, 1984; Individuation, 1994]

\section{Субсистенція}

Субсистенція (subsistentia) - це спосіб існування, коли річ $є$ незалежною від інших речей. Коли «субсистенція» вживається як абстрактний термін, вона позначає спосіб існування per se, що властивий субстанціям, на відміну від акцидентів. Ужита ж як конкретний термін, вона позначає субстанційну сутність у відношенні до 
існування. Конкретна субсистенція називається також супозит (suppositum), що є перекладом грецького «hypostasis». До цього терміну прив'язане інше філософське поняття - «особа» (persona). Особа - це супозит, що володіє розумом, наприклад, Бог, ангел, людина.

Близьким за значенням до поняття «супозит» $є$ поняття «природа» (natura). Проте ці два поняття чітко розрізняються у теологічному контексті. У Св. Трійці є три Особи, при цьому друга Особа св. Трійці має дві природи: божественну і людську.

В латинську схоластику поняття «супозит» увійшло як переклад грецького «hypostasis». Однак «hypostasis» спочатку перекладалось як «субстація» (substantia), що було джерелом непорозумінь, оскільки субстанція використовувалася також для перекладу грецького «оv่бía».

У пізніший період поняття субсистенція поставало як джерело дискусій між томістами і скотистами. На думку Томи Аквінського, природа і супозит розрізняються реально в речах, що складаються з форми і матерії. Супозит додає до природи додатковий позитивний елемент, а саме індивідуальну матерію.

На думку Дунса Скота, субсистенція $є$ не чимось позитивним, а просто запереченням залежності від іншого сущого. (Cf. [Mullaney, 2002])

\section{Погляди Інокентія Гізеля}

Еклектичний підхід Інокентія Гізеля, чітко простежуваний у розв'язанні ним проблеми універсалій, а також в антропології, виявляє себе й у метафізиці. Слідом за скотистами, Гізель вважає, що сутність та існування розрізняються лише розумово, так само він приймає оцейність, як принцип індивідуації. Одначе у питанні про субсистенцію могилянський професор не погоджується зі скотистами й вважає, слідом за томістами, що супозит додає до речі щось позитивне.

\section{СПИСОК ЛІТЕРАТУРИ}

Гізель I. Твір про всю філософію // Гізель І. Вибрані твори в 3-х тт. - Київ-Львів: Свічадо, 2011. - T. 2. - C. 5-407.

Пітч P. «Tractatus de Anima» Інокентія Гізеля в контексті антропологічних ідей Аристотеля та його схоластичних інтерпретаторів // Гізель І. Вибрані твори в 3-х тт. - Київ-Львів: Свічадо, 2010. - Т. 3. - С. 31-50.

Симчич М. Проблема розрізнень і універсалій у філософському курсі Інокентія Гізеля // Гізель І. Вибрані твори в 3-х тт. - Київ-Львів: Свічадо, 2010. - Т. 3. - С. 83-102.

Стратій Я. Інтерпретація проблеми сутності душі та її здатностей у «Трактаті про душу» Інокентія Гізеля // Гізель І. Вибрані твори в 3-х тт. - Київ-Львів: Свічадо, 2010. - Т. 3. - C. $51-81$.

Gracia J.J.E. Introduction to the Problem of Individuation in the Early Middle Ages. - MünchenWien: Philosophia Velag, 1984.

Individuation in Scholasticism. The Later Middle Ages and the Counter-Reformation 1150-1650. / edited by Jorge J. E. Gracia. - Albany: SUNY, 1994.

Macdonald $S$. The "Esse/Essentia" Argument in Aquinas's "De ente et essentia" // Journal of the History of Philosophy, 22:2 (1984:Apr.) - p.157172.

Mullaney T.U. Subsistence // New Catholic Encyclopedia. (2 ed.) - Detroit-Washington DC: Gale, Catholic University of America, 2002 - Vol. 13. - P. 570585.

Owens J. An Iinterpretation of Existence. - Milwaukee: Bruce Pub. Co., 1968.

Стаття одержана редакцією 24.11.2013 


\section{Mykola Symchych}

\section{Inokentii Gizel: Some Metaphysical Questions from Philosophical Course}

The investigation is devoted to Inokentii Gizel's metaphyisical views, according to his philosophical course Opus totius philosophiae (Kyiv Mohyla Academy, 1645-1647); a passage of it, for the first time, deciphered and translated into Ukrainian, is published in the appendix to this article. The author analyzes Gizel's position on the three important problems of scholastic metaphysics (the distinction between essence and existence, the principle of individuation and subsistence). The author argues that the solution of these questions completely agrees with Gizel's «eclectic tendency» manifested in the combination of Thomistic and Scotistic ideas: Gizel follows Scotists in the questions about the distinction of essence and existence as well as the principle of existence; however, he accepts the Thomistic position in the issue of subsistence.

Mykola Symchych, PhD in philosophy, research fellow at the Department of the History of Ukrainian Philosophy, Skovoroda's Institute of Philosophy, the National Academy of Sciences of Ukraine

Микола Симчич, кандидат філософських наук, науковий співробітник відділу історії філософї Украӥни Інституту філософії ім. Г. С. Сковороди НАН Украӥни

Николай Симчич, кандидат философских наук, научный сотрудник отделения истории философии Украины Института философии им. Г. С. Сковороды НАН Украины 